stage, a courtyard for dance displays, an artists' workshop, and a library. In addition the Institute sponsors the Ife Festival of Arts, first held in December 1968, which is to become an annual event for the display of a wide variety of cultural activities. An International Seminar on Cultural Diversity and National Understanding within West African Countries was held from 14 to 19 December 1970 and an account of this will be given in a later issue of Africa. Publications sponsored by the Institute of African Studies include Odu: a Journal of West African Studies; the Institute is also one of the sponsors of the new West African Journal of Archaeology.

\title{
University of Nairobi: Institute of Development Studies (see Africa, xxxvi, April, 1966, P. 201)
}

The Institute of Development Studies of the University of Nairobi was established in 1969. Its report published in July 1970 lists its activities, research projects, and publications under its present Director, Professor J. S. Coleman. Research has been concentrated mainly in the fields of agriculture and rural development, urban and industrial development and education, including studies on agricultural pricing and market policies in Kenya (T. J. Aldington and others); the role of chiefs and sub-chiefs in administration in Kenya (N. Nyangira); relations between the co-operative movement and the government in Kenya from 1945 to 1970 (E. Karanja); rural urban migration in Kenya (M. P. Todaro and others); and a comparative study of development of higher education in eastern Africa (J. S. Coleman).

\section{Institut für Bibelübersetzung, Philipps-Universität, Marburg (Lahn)}

UNDER the sponsorship of the Evangelisches Bibelwerk, Berlin, a new research centre, the Institute for Bible Translation, has been created under the direction of Professor Enst Dammann at the Philipps-Universität, Marburg (Lahn). In addition to lectures, courses, and conferences, the Institute plans to establish a central depository of minutes, reports, letters, memoirs, private publications, etc.-published and unpublished-concerned with Bible translation in the past and present, including dictionaries, wordlists, and relevant literature from periodicals and books. These materials will be collected, catalogued, and housed in Marburg. Particular emphasis will be laid on the nineteenth and twentieth centuries -the great period of missionary expansion and translation - and the scope of the work will be oecumenical and interdenominational. Its materials will be placed at the disposal of all those persons and organizations wishing to make use of them. Attention will be focused on one geographical area at a time and a start has been made with East and East Central Africa, i.e. Uganda, Kenya, Zambia, and Malawi.

\section{Université Lovanium de Kinshasa: Department of History}

THE Department of History was established in October 1966 . Its curriculum includes two undergraduate years, leading to the Candidature, and two graduate years, leading to the Licence. It now enrolls approximately one hundred students, originating mostly from the Congo, Rwanda, and Burundi. The staff includes six professors, of whom five specialize in African History, three assistants, and visiting professors. Teaching and research lay emphasis on the History of Central Africa, though specialization mainly takes place during the last two Licence years. For Licence dissertations, stress is laid on research into local history, based both on available archives and oral tradition.

In 1970 the Department published a volume of essays, entitled Etudes d'Histoire africaine, i (Nauwelaerts Publishing House, Louvain, Belgium). It intends publishing one volume per year. Contributions in French or English are welcome and may be submitted to the editorial 